\begin{tabular}{|c|c|}
\hline 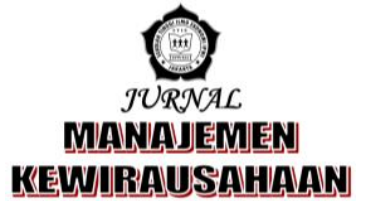 & $\begin{array}{r}\text { p-ISSN 1858-1048 } \\
\text { e-ISSN 2654-9247 } \\
\text { http://ejurnal.stieipwija.ac.id/index.php/jmk } \\
\text { DOI: http://dx.doi.org/10.33370/jmk.v16i2.340 } \\
\text { Jurnal Manajemen Kewirausahaan Vol. 16 No. 02 - Desember 2019 } \\
\text { Submit: 29 Nov 2019; Review: 05 Des 2019; Publish: 13 Jan } 2019\end{array}$ \\
\hline
\end{tabular}

\title{
PENGARUH STRES KERJA DAN KUALITAS KERJA TERHADAP KINERJA KURIR DOKUMEN \\ (STUDI KASUS JASA PENGIRIMAN PT. PRIMA MULTI CIPTA, JAKARTA SELATAN)
}

\author{
Oleh: \\ Venty Melani' ${ }^{1)}$, Agus Sudigdo') \\ venty.melani10@gmail.com ${ }^{11}$, agus.sudigdo@gmail.com²) \\ Sekolah Tinggi Ilmu Ekonomi Unisadhuguna1), Sekolah Tinggi Ilmu Ekonomi IPWI Jakarta2)
}

\begin{abstract}
ABSTRAK
This study aims to determine whether there is an influence of work stress and employee work quality on the performance of the courier at PMC South Jakarta branch. This research was conducted in August 2019 through distribution of questionnaires. The population in this study is the Courier at PT. PMC. 50 respondents answer were obtained through a questionnaire about work stress and employee work quality. The instrument testing method used is validity and reliability test. The data analysis technique used is quantitative descriptive technique, multiple linear regression analysis, and $t$ test.

Based on the research results, it was concluded that there was a significant impact of work stress on performance, and there is a positive and significant effect of employee work quality on performance.
\end{abstract}

Kata Kunci: job stress, work qualilty, performance

\section{PENDAHULUAN}

PT. Prima Multi Cipta (PMC) merupakan perusahaan yang bergerak pada sektor usaha layanan kurir atau jasa pengiriman. PMC terus berupaya meningkatkan kinerja seluruh kurirnya melalui langkah/program efisiensi maupun efektivitass pengiriman seperti membentuk budaya kerja positif yang pada akhirnya diyakini mampu meningkatkan kepuasan serta produktivitas para karyawan dan kinerja perusahaan secara keseluruhan.

Namun, pada kenyataanya saat ini kinerja karyawan PMC cabang Jakarta Selatan belum memuaskan atau dengan kata lain tidak semuanya mencapai target yang telah ditetapkan. Hal ini disebabkan oleh beberapa faktor seperti jumlah loading dokumen dalam sebulan mencapai 300.000 dokumen untuk 50 karyawan, dan target yang cukup tinggi di mana setiap karyawan harus mencapai pengiriman 200 dokumen dalam sehari, sedangkan aktualnya hanya $50 \%$ dokumen yang berhasil dikirim dalam satu hari.

Demi mendapatkan keunggulan kompetitif, efisiensi, dan dan dapat bersaing dalam pasar yang kian ketat, maka peningkatan kualitas sumber daya manusia dalam organisasi merupakan salah satu cara guna meningkatkan kinerja karyawan. Kinerja karyawan ialah faktor krusial untuk diteliti karena variabel ini adalah tolak ukur 
keberhasilan perusahaan, atau sebaliknya.

PMC cabang Jakarta Selatan menghadapi berbagai permasalahan dan tantangan di masa mendatang, dan penyebab utama tidak tercapainya target perusahaan dikarenakan sumber daya manusia serta manajemen dalam perusahaan yang kurang memperhatikan kualitas kerja dan tingkat stres karyawan sehingga rendahnya kinerja yang dihasilkan. Salah satu faktor yang dapat mempengaruhi keberhasilan suatu organisasi adalah kinerja karyawan. Untuk meningkatkan kinerja karyawan, maka perusahaan harus memperhatikan stres kerja karyawan di mana hal ini dapat terjadi pada setiap individu/manusia pada setiap waktu, karena stres merupakan bagian dari kehidupan manusia yang tidak dapat dihindarkan. Manusia akan cenderung mengalami stres apabila ia kurang mampu menyesuaikan antara keinginan dengan kenyataan yang ada, baik kenyataan yang ada di dalam maupun di luar dirinya.

\section{TUJUAN PENELITIAN}

Berikut merupakan beberapa tujuan utama dalam penelitian ini, antara lain:

- Menganalisis pengaruh stres kerja terhadap kinerja karyawan.

- Menganalisis pengaruh kualitas kerja terhadap kinerja karyawan.

- Menganalisis pengaruh simultan stres kerja dan kualitas kerja terhadap kinerja karyawan.

\section{TELAAH LITERATUR DAN PENGEMBANGAN PROPOSISI/HIPOTESIS}

Dari perspektif historis, kata 'manajemen' berasal dari bahasa Prancis, yakni management yang berarti sebuah seni dalam mengatur, merencanakan, serta melaksanakan. Selain itu, manajemen juga dapat didefinisikan sebagai suatu proses perencanaan, koordinasi, pengorganisasian, dan kontrol sumber daya guna terciptanya efektivitas dan efisiensi organisasi. Efektif dalam konteks ini ialah bertujuan untuk mencapai tujuan yang telah ditetapkan di awal, dan efisien dalam hal ini berarti mampu bekerja secara benar dan terorganisir dengan baik.

Selanjutnya, manajemen berfungsi sebagai fundamental atau dasar pijakan para manajer dalam melaksanakan tugas sehari-hari, dan agar dapat mencapai tujuan melalui proses perencanaan, koordinasi, pengorganisasian, dan kontrol yang tepat.

\section{Stres Kerja}

Secara umum, definisi stres berarti suatu kondisi tegang yang membuat tidak nyaman karena seseorang secara subjektif menilai/merasa ada sesuatu yang sedang membebani dirinya. Stres merupakan bentuk tanggapan adaptif, dan dibatasi oleh sebuah proses psikologis, dan juga perbedaan individual, yaitu konsekuensi langsung dari tiap kegiatan yang dilakukan di lingkungan, dan situasi eksternal yang memberikan beban secara psikologis ataupun fisik yang berlebih kepada seseorang. Stres umum didefinisikan sebagai suatu gejala atau keadaan di mana diri dan jiwa seseorang terasa tertekan di luar batas kemampuanya, sehingga apabila terus dibiarkan tanpa solusi, maka hal tersebut akan berimplikasi pada kesehatannya (Irham Fahmi, 2016:277).

Stres kerja merupakan rasa tertekan yang dialami oleh individu/ karyawan dalam menghadapi tugas pekerjaan sehari-hari (Mangkunegara, 2011:157). Hal ini terlihat dari tanda/ gejala yang nampak seperti emosi yang tidak stabil, insomnia, perasaan tidak nyaman, merokok sangat aktif/ berlebihan, tidak rileks, cemar berlebih, gugup, tegang, tensi meningkat, dan juga masalah pada pencernaan serta tekanan darah.

Selain itu, stres kerja juga didefinisikan sebagai situasi yang dihadapi oleh individu di mana mereka mengalami nervous, rasa khawatir berlebihan, emosional, dan tidak dapat 
menunjukkan sikap yang kooperatif (Hasibuan, 2012:204).

\section{Faktor-Faktor yang Mempengaruhi Stres Kerja}

Terdapat sejumlah faktor yang dapat menciptakan stres kerja karyawan di mana hal ini dapat berasal dari stres individu, perusahaan, maupun dari work environment. Sementara itu, penyebab stres kerja karyawan lainnya menurut Mangkunegara, (2011:157) antara lain sebagai berikut:

- Desakan dan Tekanan Waktu.

- Beban kerja yang berlebih.

\section{Dampak Stres Kerja}

Stres kerja tentunya berimplikasi negatif pada mental maupun fisik seseorang. Hal ini harus dihadapi dan direspon oleh orang tersebut sehingga cara menghadapi stres kerjalah yang dapat membentuk dinamika perilaku seseorang.

- Kesehatan. Tubuh manusia dilengkapi dengan antibodi sehingga stres yang dihadapi dapat berimplikasi atau dengan kata lain dapat menimbulkan penyakit pada diri seseorang.

- Psikologis. Rasa khawatir berlebih, tegang ataupun risau secara kontinyu dapat membuat seseorang menjadi putus asa, dan bahkan dapat menimbulkan niat bunuh diri atau keinginan untuk mati saja.

\section{Kualitas Kerja}

Kualitas merupakan karakteristik yang dimiliki suatu layanan atau produk yang berupaya untuk memuaskan kebutuhan tertentu (Russel dan Taylor, 2000:78). Kualitas dinilai sebagai suatu kemampuan produk atau layanan dalam memenuhi kebutuhan pelanggan (Heizer dan Render, 2000:171).

Kualitas kerja atau produktivitas menunjukkan tingkah laku sebagai keluaran (output) dari suatu proses berbagai macam komponen kejiwaan yang melatar belakanginya. Kualitas atau produktivitas kerja dihasilkan dari suatu proses panjang dan berbagai macam elemen yang membentuknya. Terdapat beberapa faktor yang mempengaruhi kualitas kerja seseorang yang dikemukakan oleh Simanjuntak seperti pelatihan, mental positif, dan kemampuan fisik, hubungan kerja. Selanjutnya, kualitas kerja menurut Hasibuan merupakan bagaimana dapat meningkatkan hasil barang dan jasa setinggi mungkin dengan mengoptimalisasi resources secara efisien. Kualitas kerja ialah sebuah rasio antara waktu yang dibutuhkan dengan hasil kerja untuk peningkatan hasil setinggi mungkin dengan pemanfaatan resources seminim mungkin (Hasibuan, 2008:110).

Untuk meningkatkan performance quality (kualitas kerja) ada beberapa cara yang dapat dilakukan oleh perusahaan, seperti pemberian bonus, insentif, training, implementasi teknologi guna peningkatan efektivitas dan efisiensi kerja (Bitner dan Zeithaml dalam Riorini, 2004:22).

\section{Indikator Kualitas Kerja}

Kualitas kerja memiliki beberapa indikator utama. Pertama, orientasi intelejensi. Kedua, pemberian pelatihan. Ketiga, daya berpikir. Keempat, ketrampilan. Kelima, penguasaan ilmu dan pengawasan teknis (Matutina, 2001:205).

Sementara itu, indikator kualitas kerja menurut Edy Sutrisno dalam Tohardi (2012:104), antara lain:

- Tanggung jawab

Rasa tanggung jawab merupakan salah satu ukuran dalam menilai kualitas kerja seseorang.

- Target

Menetapkan target jangka pendek maupun jangka panjang, atau dengan kata lain pembuatan key performance indicator. Hal ini merupakan salah satu cara untuk mengukur kualitas kerja seorang karyawan.

- Disiplin

Tingkat disiplin dan kemampuan untuk melaksanakan tugas, disiplin kerja pada jam kerja, istirahat, dalam proses bekerja dan patuh pada prosedur kerja merupakan indikator untuk mengukur dan 
dapat memacu kualitas kerja karyawan.

\section{Kinerja}

Kinerja karyawan merupakan pencapaian karyawan dalam memenuhi berbagai persyaratan pekerjaan (Simamora, 2004:27). Kinerja ialah pencapaian kerja yang dillihat dari pencapaian kuantitas dan kualitas kerja seorang individu dalam melaksanakan berbagai (Mangkunegara, 2011:67).

Kinerja karyawan juga umum didefinisikan sebagai hasil yang dicapai karyawan dalam konteks pencapaian tugas-tugas yang dieemban yang didasari oleh pengalaman, kesungguhan, serta kecakapan dan waktu (Hasibuan, 2001:34).

\section{Pengaruh Stres Kerja dan Kualitas Kerja Terhadap Kinerja}

Gejala stres umumnya dapat terlihat dari sikap individu yang menjadi sering marah, tidak rileks, tidak kooperatif dan bisa juga melakukan tindakan menyimpang seperti minum alkohol, merokok secara berlebihan dan konsumsi narkoba (Wahjono, 2010). J.P Chaplin mengungkapkan bahwa stres merupakan kata benda di mana menggambarkan suatu situasi fisik/psikologis yang sedang tertekan. Makna stres bila dilihat dari perannya sebagai kata kerja, maka hal ini berarti memberikan tekanan atau upaya yang dilakukan oleh atasan terhadap bawahannya agar mereka memiliki suatu perilaku kompetitif dan produktif.

Stres kerja tentunya dapat memberikan efek negatif pada diri seorang karyawan. Jika karyawan mengalami stres, maka hal ini dapat menyebabkan gangguan psikis dan fisik, dan kondisi tersebut tentunya dapat berdampak negatif atau dengan kata lain kinerja karyawan dan perusahaan dapat menurun. Ketika kinerja karyawan menurun akibat stres, maka hal tersebut juga menurunkan kinerja perusahaan secara menyeluruh. Hal ini tentu saja dapat berpengaruh pada tidak tercapainya tujuan maupun target perushaan, sehingga perusahaan tidak mampu lagi mempertahankan serta bersaing dengan kompetitor di saat ini dan di masa mendatang.

\section{Kerangka Pemikiran}

Berikut adalah beberapa hipotesis yang diajukan dalam studi ini, antara lain:

$\mathrm{H}_{1}$ : Terdapat pengaruh stres kerja terhadap kinerja karyawan.

$\mathrm{H}_{2}$ : Terdapat pengaruh kualitas kerja karyawan terhadap kinerja karyawan.

$\mathrm{H}_{3}$ : Terdapat pengaruh stres kerja dan kualitas kerja karyawan secara simultan terhadap kinerja karyawan. Gambar 1

Kerangka/Konstelasi

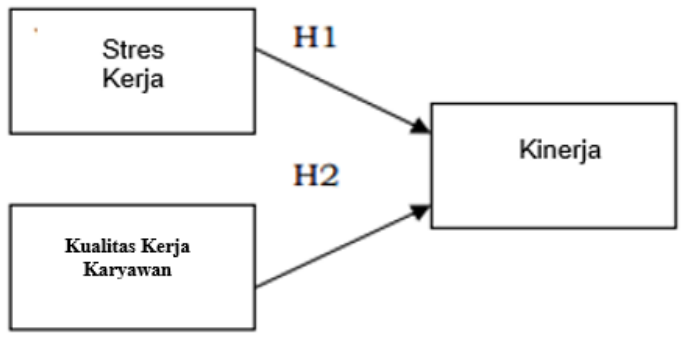

\section{METODE PENELITIAN \\ Sampel Penelitian}

Pengambilan sampel dalam penelitian ini menggunakan pendekatan purposive sampling di mana terdapat beberapa kriteria khuss dalam pengambilan sampel seperti responden harus bekerja sebagai kurir di PMC Cabang Jakarta Selatan. Setelah kuesioner disebarkan selama bulan Oktober 2019, maka berhasil terkumpul 50 sampel yang sesuai dengan kriteria penelitian.

\section{Desain Penelitian}

Penelitian ini menggunakan pendekatan kuantitatif di mana data dikumpulkan dengan cara mendistribusikan kuisioner secara langsung (data primer). Peneliti memberikan seperangkat pernyataan/pertanyaan tertulis dan instruksi secara lisan.

Kuisioner merupakan instrumen yang digunakan oleh peneliti untuk mengumpulkan jawaban/data dari responden di mana pernyataan/pertanyaan tertulis dijawab 
oleh responden secara langsung. Kuesioner dalam studi ini menggunakan skala likert, skala ini bertujuan untuk mengukur persepsi individu/kelompok terkait dengan fenomena sosial yang terjadi (Sugiyono, 2009).

Dalam studi ini, kuesioner terdiri dari empat pertanyaan untuk variabel $\mathrm{X}_{1}$ dan empat pertanyaan untuk variabel $\mathrm{X}_{2}$ dan lima pertanyaan untuk variabel $\mathrm{Y}$ yang diberikan secara langsung kepada 50 orang kurir PMC cabang Jakarta Selatan.

\section{Operasionalisasi Variabel}

Operasionalisasi masing-masing variabel yang digunakan dalam penelitian ini, antara lain sebagai berikut:

Tabel 1

Operasionalisasi Variabel

\begin{tabular}{|c|c|c|}
\hline Variabel & Indikator & Skala \\
\hline $\begin{array}{l}\text { Stres kerja }\left(\mathrm{X}_{1}\right) \\
\text { Sumber: } \\
\text { Mangkunegara, } \\
(2008: 157)\end{array}$ & $\begin{array}{l}\text { - Beban Kerja } \\
\text { - Waktu } \\
\text { - Kualitas } \\
\text { Pengawasan }\end{array}$ & \multirow{3}{*}{ Likert } \\
\hline $\begin{array}{c}\text { Kualitas Kerja }\left(\mathrm{X}_{2}\right) \\
\text { Sumber: Hasibuan } \\
(2010: 94)\end{array}$ & $\begin{array}{l}\text { - Target } \\
\text { - Disiplin } \\
\text { - Tanggung } \\
\text { Jawab } \\
\end{array}$ & \\
\hline $\begin{array}{c}\text { Kinerja }(\mathrm{Y}) \\
\text { Sumber: Sugiono, } \\
(2009: 90)\end{array}$ & $\begin{array}{l}\text { - Prestasi } \\
\text { - Kerja sama } \\
\text { - Loyalitas }\end{array}$ & \\
\hline
\end{tabular}

Sumber: Diolah dari berbagai sumber

\section{Metode Analisis}

Analisis data dilakukan melalui uji validitas dan reliabilitas yang bertujuan untuk melihat apakah alat ukur yang digunakan layak digunakan/ mampu mengukur setiap konstruk atau sebaliknya. Selanjutnya, peneliti menguji data melalui uji asumsi klasik yang digunakan untuk melihat normalitas data, dan gejala Heteroskedastisitas.

Teknik analisis data yang digunakan dalam penelitian ialah menggunakan pendekatan regresi linier berganda di mana hal ini bertujuan untuk membuktikan hipotesis penelitian yang telah diajukan, serta melihat seberapa besar pengaruh masingmasing variabel independen (prediktor) terhadap variabel dependen dalam penelitian ini.

\section{HASIL DAN PEMBAHASAN}

Berdasarkan hasil penelitian, dapat diketahui deskripsi untuk masingmasing variabel penelitian. Deskripsi dari variabel penelitian ini juga dijelaskan dari tiap indikator.

\section{Uji Validitas}

Uji validitas merupakan cara untuk mengukur validitas indikator yang digunakan dalam penelitian atau dengan kata lain yang terdapat pada instrumen kuesioner penelitian (Ghozali, 2016:52). Berikut adalah hasil uji validitas dalam penelitian ini:

Tabel 2

Uji Validitas Variabel Stres Kerja $\left(\mathrm{X}_{1}\right)$

\begin{tabular}{|c|c|c|c|}
\hline \multirow{2}{*}{ Pernyataan } & \multicolumn{3}{|c|}{ Stres Kerja $\left(\mathbf{X}_{\mathbf{1}}\right)$} \\
\cline { 2 - 4 } & r hitung & $\begin{array}{c}\text { R tabe1 } \\
\text { n= 100 }\end{array}$ & Ket \\
\hline 1 & 0,875 & 0,278 & Valid \\
\hline 2 & 0,835 & 0,278 & Valid \\
\hline 3 & 0,869 & 0,278 & Valid \\
\hline 4 & 0,819 & 0,278 & Valid \\
\hline
\end{tabular}

Berdasarkan tabel di atas, dapat dilihat bahwa masing-masing indikator pada variabel Stres Kerja $\left(\mathrm{X}_{1}\right)$ menunjukkan seluruh instrumen dapat dikatakan valid, karena nilai $r_{\text {hitung yang }}$ dihasilkan lebih besar daripada nilai $\mathrm{r}_{\text {tabel }}$ yang ada untuk $\mathrm{df}=\mathrm{n}-2=48$, yaitu 0,278 .

Tabel 3

Uji Validitas Variabel Kualitas Kerja $\left(\mathrm{X}_{2}\right)$

\begin{tabular}{|c|c|c|c|}
\hline \multirow{2}{*}{ Pernyataan } & \multicolumn{3}{|c|}{ Kualitas Kerja $\left(\mathbf{X}_{\mathbf{2}}\right)$} \\
\cline { 2 - 4 } & r hitung & $\begin{array}{r}\text { r tabe1 } \\
\mathbf{n}=\mathbf{1 0 0}\end{array}$ & Ket \\
\hline 1 & 0,746 & 0,278 & Valid \\
\hline 2 & 0,785 & 0,278 & Valid \\
\hline 3 & 0,677 & 0,278 & Valid \\
\hline 4 & 0,788 & 0,278 & Valid \\
\hline
\end{tabular}

Berdasarkan tabel di atas, dapat dilihat masing-masing indikator/ pernyataan pada variabel Kualitas Kerja $\left(\mathrm{X}_{2}\right)$ dapat dikatakan valid, karena nilai $r_{\text {hitung }}$ yang dihasilkan lebih besar daripada nilai $r_{\text {tabel }}$ di mana $\mathrm{df}=\mathrm{n}-2=48$, yaitu 0,278 . 
Tabel 4

Uji Validitas Variabel Kinerja (Y)

\begin{tabular}{|c|c|c|c|}
\hline \multirow{2}{*}{ Pernyataan } & \multicolumn{3}{|c|}{ Kinerja (Y) } \\
\cline { 2 - 4 } & r hitung & $\begin{array}{c}\text { r tabe1 } \\
\text { n = 100 }\end{array}$ & Ket \\
\hline 1 & 0,792 & 0,278 & Valid \\
\hline 2 & 0,873 & 0,278 & Valid \\
\hline 3 & 0,895 & 0,278 & Valid \\
\hline 4 & 0,792 & 0,278 & Valid \\
\hline 5 & 0,944 & 0,278 & Valid \\
\hline
\end{tabular}

Berdasarkan tabel di atas, menunjukkan masing-masing pernyataan pada variabel Kinerja (Y) dapat dikatakan valid, karena nilai $r_{\text {hitung }}$ yang dihasilkan lebih besar daripada nilai $r_{\text {tabel }}$ di mana $\mathrm{df}=\mathrm{n}-2=48$, yaitu 0,278 .

\section{Uji Reliabilitas}

Uji reliabilitas merupakan suatu cara untuk melihat konsistensi indikator yang digunakan dalam suatu penelitian atau dengan kata lain instrumen yang digunakan dalam penelitian harus dapat dipercaya atau reliable.

Tabel 5

Uji Reliabilitas Variabel Stres kerja $\left(\mathrm{X}_{1}\right)$

\section{Reliability Statistics}

\begin{tabular}{|c|c|}
\hline $\begin{array}{c}\text { Cronbach's } \\
\text { Alpha }\end{array}$ & N of Items \\
\hline .858 & 4 \\
\hline
\end{tabular}

Berdasarkan tabel di atas, untuk uji reliabilitas variabel Stres Kerja $\left(\mathrm{X}_{1}\right)$ dengan nilai Cronbach's Alpha sebesar 0.858, hal ini menunjukan bahwa instrumen penelitian yang digunakan reliable karena $0,858>0,60$ sehingga dapat disimpulkan instrumen penelitian mengenai variabel Stres Kerja $\left(\mathrm{X}_{1}\right)$ adalah Reliabel.

Tabel 6

Uji Reliabilitas Kualitas Kerja $\left(\mathrm{X}_{2}\right)$ Reliability Statistics

\begin{tabular}{|c|c|}
\hline $\begin{array}{c}\text { Cronbach's } \\
\text { Alpha }\end{array}$ & N of Items \\
\hline .729 & 4 \\
\hline
\end{tabular}

Berdasarkan tabel di atas, untuk uji reliabilitas variabel Kualitas Kerja $\left(\mathrm{X}_{2}\right)$ dengan nilai Cronbach's Alpha sebesar 0.729, hal ini menunjukan bahwa instrumen penelitian yang digunakan reliable karena 0,729 $>0,60$ sehingga dapat disimpulkan instrumen penelitian mengenai variabel Kualitas Kerja $\left(\mathrm{X}_{2}\right)$ adalah reliabel.

Tabel 7

Uji Reliabilitas Variabel Kinerja (Y) Reliability Statistics

\begin{tabular}{|c|c|}
\hline $\begin{array}{c}\text { Cronbach's } \\
\text { Alpha }\end{array}$ & N of Items \\
\hline .917 & 5 \\
\hline
\end{tabular}

Berdasarkan tabel di atas, untuk uji reliabilitas variabel Kinerja (Y) dengan nilai Cronbach's Alpha sebesar 0.917, hal ini menunjukan bahwa instrumen penelitian yang digunakan reliable karena 0,917 $>0,60$ sehingga dapat disimpulkan instrumen penelitian mengenai variabel Kinerja (Y) reliabel.

\section{Uji Asumsi Klasik Uji Normalitas}

Gambar 2

Uji Normalitas

Normal P-P Plot of Regression Standardized Residual

Dependent Variable: Kinerja

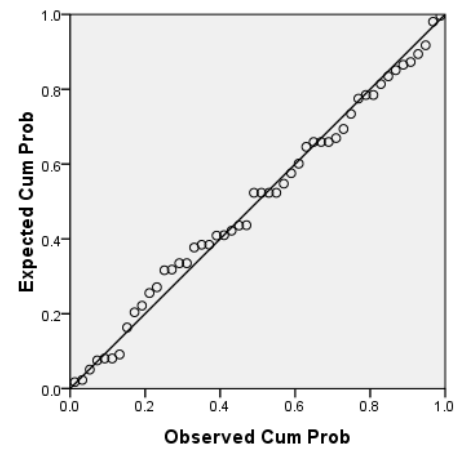

Berdasarkan hasil uji normalitas di atas (normality plot) memperlihatkan bahwa titik mengikuti garis diagonal, maka hal ini berarti data berdistribusi normal (Ghozali, 2011-160-161).

\section{Uji Heteroskedastisitas}

Dari output di bawah ini dapat diketahui bahwa titik-titik tidak membentuk pola yang jelas, dan titik- 
titik menyebar di atas dan di bawah angka 0 pada sumbu $Y$. Jadi dapat disimpulkan bahwa tidak terjadi masalah heteroskedastisitas dalam model regresi.

\section{Gambar 3}

Uji Heteroskedastisitas Scatterplot

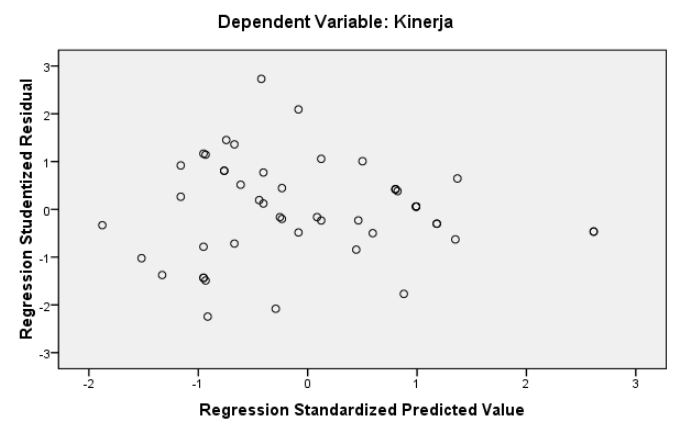

Dari output di atas dapat diketahui bahwa titik-titik tidak membentuk pola yang jelas, dan titik-titik menyebar di atas dan di bawah angka 0 pada sumbu Y. Jadi dapat disimpulkan bahwa tidak terjadi masalah heteroskedastisitas dalam model regresi.

\section{Analisis Regresi Linear Berganda}

Tabel 8

Regresi Linier Berganda

\begin{tabular}{|c|c|c|c|c|c|}
\hline \multirow[b]{2}{*}{ Vodel } & \multicolumn{2}{|c|}{$\begin{array}{l}\text { Unstandardizec } \\
\text { Coefficients }\end{array}$} & \multirow{2}{*}{\begin{tabular}{|l} 
Stardardize \\
d \\
Coefficients \\
Be:â
\end{tabular}} & \multirow{2}{*}{ t } & \multirow[b]{2}{*}{ Siq. } \\
\hline & $B$ & Std. Error & & & \\
\hline Constantị & -369 & 1.068 & & .346 & .731 \\
\hline Stres Kerja & $\angle 88$ & .087 & 501 & 5.722 & .000 \\
\hline $\begin{array}{c}\text { Kualitas } \\
\text { Kerja }\end{array}$ & 554 & 101 & .479 & 5.463 & .000 \\
\hline
\end{tabular}

Dari tabel di atas, maka model persamaan regresinya adalah:

$Y=-369+0,498 X_{1}+0,554 X_{2}$

Keterangan:

$\mathrm{Y}=$ Kinerja

$\mathrm{X}_{1}=$ Stres Kerja

$\mathrm{X}_{2}=$ Kualitas Kerja

a. Variabel stres kerja dan kualitas kerja mempunyai arah koefisien yang bertanda positif terhadap kinerja kurir.

b. Koefisien stres kerja memberikan nilai 0,498 yang berarti bahwa semakin stres kerja meningkat, maka kinerja kurir akan semakin menurun.

c. Koefisien Kualiltas Kerja memberikan nilai 0,554 yang berarti bahwa semakin produktif maka kinerja akan semakin naik.

\section{Pengaruh Stres Kerja $\left(X_{1}\right)$ terhadap Kinerja Kurir (Y)}

Tabel 9

Analisis Hipotesis 1

\begin{tabular}{|c|c|c|c|c|c|}
\hline \multirow[b]{2}{*}{ Vodel } & \multicolumn{2}{|c|}{$\begin{array}{l}\text { Unstandardizec } \\
\text { Coefficients }\end{array}$} & \multirow{2}{*}{$\begin{array}{l}\text { Stardardize } \\
\text { d } \\
\text { Coefficients } \\
\text { Beta }\end{array}$} & \multirow[b]{2}{*}{$\mathrm{t}$} & \multirow[b]{2}{*}{ Siq. } \\
\hline & $B$ & Std. Error & & & \\
\hline Constanti & -369 & 1.068 & & -.346 & .731 \\
\hline Stres Kerja & $\angle 88$ & .087 & 501 & 5.722 & .000 \\
\hline $\begin{array}{c}\text { Kualitas } \\
\text { Kerja }\end{array}$ & 554 & 101 & 479 & 5.463 & .000 \\
\hline
\end{tabular}

$$
\begin{aligned}
& t_{\text {hitung }}=5,722 \\
& \mathrm{t}_{\text {table }}=2,012(\mathrm{n}-\mathrm{k} ; 50-3=47)
\end{aligned}
$$

Berdasarkan hasil pengujian secara parsial pengaruh antara stres kerja terhadap kinerja kurir diperoleh thitung $(5,722)>\mathrm{t}$ table $(2,012)$, dengan taraf signifikan $0,00<0,05$. Nilai 5,722 lebih besar dari 2,012 menunjukan $\mathrm{t}$ hitung lebih besar dari $t$ table. Hal ini menunjukan bahwa ada pengaruh yang signifikan antara stres kerja terhadap kinerja.

\section{Pengaruh Kualitas Kerja $\left(\mathrm{X}_{2}\right)$ terhadap Kinerja Kurir (Y)}

Tabel 10

\begin{tabular}{|c|c|c|c|c|c|}
\hline \multirow[b]{2}{*}{ Vodel } & \multicolumn{2}{|c|}{$\begin{array}{l}\text { Unstandardizec } \\
\text { Coefficients }\end{array}$} & \multirow{2}{*}{$\begin{array}{l}\text { Stardardize } \\
\text { d } \\
\text { Coefficients } \\
\text { Be:a }\end{array}$} & \multirow{2}{*}{ t } & \multirow[b]{2}{*}{ Siq. } \\
\hline & $B$ & Std. Error & & & \\
\hline iConstanti & -369 & 1.068 & & -346 & .731 \\
\hline Stres Kerja & 488 & .087 & 501 & 5.722 & .000 \\
\hline $\begin{array}{c}\text { Kualitas } \\
\text { Kerja }\end{array}$ & 554 & .101 & 479 & 5.463 & .000 \\
\hline
\end{tabular}

Analisis Hipotesis 2

Data di atas dan pengelolaan SPSS dapat diketahui:

$\mathrm{t}_{\text {hitung }}=5,468$

$\mathrm{t}_{\text {table }}=2,012(\mathrm{n}-\mathrm{k} ; 50-3=47)$ 
Berdasarkan hasil pengujian secara parsial pengaruh antara kualitas kerja terhadap kinerja kurir diperoleh t hitung $(5,468)>t$ table $(2,012)$, dengan taraf signifikan $0,000<0,05$. Nilai 5,468 lebih besar dari 2,012 menunjukan $t$ hitung lebih besar dari $t$ table. Hal ini menunjukan bahwa ada pengaruh yang signifikan antara kualitas kerja terhadap kinerja.

\section{Uji F}

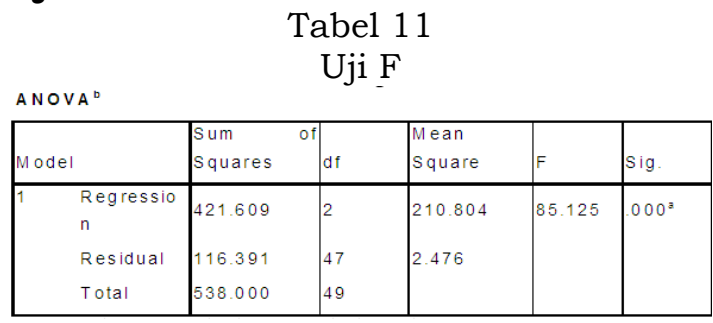

Dari data diolah dengan menggunakan SPSS dapat diketahui:

$$
\begin{array}{ll}
\mathrm{F} & =85.125 \\
\mathrm{~F}_{\text {table }} & =3,20(\mathrm{df} 1=\mathrm{k}-1 ; \mathrm{df} 2=\mathrm{n}-\mathrm{k})
\end{array}
$$

Berdasarkan tabel di atas dapat diketahui bahwa f hitung adalah 85.125 dengan tingkat signifikan 0,000 sedangan $\mathrm{f}$ table 3,20 dengan signifikan 0,05 . Dengan demikian $\mathrm{f}$ hitung $>\mathrm{f}$ table yakni $85.125>3,20$ nilai 85.125 lebih besar dari 3,20 menunjukan $t$ hitung lebih besar dari t tabel, artinya Ho ditolak sehingga dapat disimpulkan bahwa ada pengaruh signifikan antara stres kerja dan kualitas kerja terhadap kinerja kurir.

\section{Koefisien Determinasi $\left(\mathbf{R}^{2}\right)$}

Tabel 12

Koefisien Determinasi

Model summary ${ }^{\circ}$

\begin{tabular}{|l|l|l|l|l|}
\hline Model & $R$ & $\begin{array}{l}\text { R } \\
\text { Square }\end{array}$ & $\begin{array}{l}\text { Adjusted } \\
\text { Square }\end{array}$ & $\begin{array}{l}\text { Std Error of } \\
\text { the Estim ate }\end{array}$ \\
\hline 1 & $885^{3}$ & .784 & 774 & 1.574 \\
\hline
\end{tabular}

Dari hasil perhitungan dapat diketahui bahwa koefisien determinasi yang diperoleh sebesar 0,784. Hal ini berarti $78,4 \%$ variasi variabel kinerja kurir (Y) dapat dijelaskan oleh kedua variabel independen, yaitu Stres Kerja $\left(\mathrm{X}_{1}\right)$, dan kualitas kerja $\left(\mathrm{X}_{2}\right)$.

\section{Pengaruh Stres Kerja Terhadap Kinerja}

Berdasarkan hasil pengujian secara parsial pengaruh antara stres kerja terhadap kinerja diproleh t hitung 5,722 $>\mathrm{t}$ tabel $(2,012)$, dengan taraf signifikan $0,000<0,05$. Nilai 5,722 lebih besar dari 2,012 menunjukan $t$ hitung lebih besar dari $\mathrm{t}$ tabel. Dari hasil tersebut dapat disimpulkan bahwa $\mathrm{Ha}$ diterima (Ho total). Hal ini menujukan bahwa ada pengaruh yang signifikan antara sters kerja terhadap kinerja.

Dengan demikian dapat disimpulkan bahwa terdapat pengaruh variabel stres kerja (X1) terhadap kinerja $(\mathrm{Y})$, artinya bahwa ada pengaruh atau hubungan yang searah antara stres kerja terhadap kinerja secara nyata.

\section{Pengaruh Kualitas Kerja Terhadap Kinerja}

Berdasarkan hasil pengujian secara parsial Pengaruh Kualitas kerja terhadap kinerja diproleh t hitung 5,468 $<\mathrm{t}$ tabel $(2,732)$, dengan taraf signifikan $0,000<0,05$. Nilai 5,468 lebih besar dari 2,732. Menunjukan t hitung lebih besar dari $\mathrm{t}$ tabel, artinya Ho ditolak Berdasarkan hasil pengujian secara parsial Pengaruh kualitas kerja terhadap kinerja diproleh $\mathrm{t}$ hitung 5,468 $<\mathrm{t}$ tabel $(2,732)$, dengan taraf signifikan $0,000<$ 0,05 . Nilai 5,468 lebih besar dari 2,732. Menunjukan t hitung lebih besar dari t tabel, artinya Ho ditolak sehingga dapat disimpulkan bahwa ada pengaruh signifikan antara kualitas kerja terhadap kinerja kurir.

Dengan demikian, dapat disimpulkan bahwa terdapat pengaruh positif dan signifikan variabel Kualitas Kerja (X2) terhadap variabel kinerja kurir (Y). artinya bahwa ada pengaruh atau hubungan yang searah antara kualitas kerja terhadap kinerja secara nyata.

\section{Pengaruh Stres dan Kualitas Kerja terhadap Kinerja Kurir}

Berdasarkan tabel di atas dapat diketahui bahwa nilai f hitung adalah 85.125 dengan tingkat signifikan 0,000 sedangkan $f$ tabel 3,20 dengan signifikan 0,05 . Dengan demikian $f$ hitung $=f$ tabel 
yakni $85.125>3,20$ nilai 85.125 lebih besar dari 3,20 menunjukan $t$ hitung lebih besar dari t tabel, artinya Ho ditolak sehingga dapat disimpulkan bahwa ada pengaruh signifikan antara stres kerja dan kualitas kerja terhadap kinerja kurir.

Dengan demikian dapat disimpulkan bahwa terdapat pengaruh positif dan signifikan stres kerja (X1) dan kualitas kerja (X2) terhadap kinerja kurir (Y) maka kedua faktor tersebut dapat membentuk kinerja kurir $(\mathrm{Y})$. Ini artinya ada pengaruh atau hubungan yang searah dan nyata antara variabel bebas (stres kerja dan kualitas kerja) terhadap variabel terikat (kinerja kurir) secara bersamaan atau dengan kata lain, jika stres kerja (X1) dan kualitas kerja (X2) ditingkatkan maka secara bersama-sama dapat pula meningkatkan kinerja karyawan $(\mathrm{Y})$.

\section{KESIMPULAN \\ Simpulan}

Berdasarkan uraian-uraian yang dikemukakan pada bab-bab sebelumnya, akhirnya penulis sampai pada bagian akhir dari jurnal ini, yaitu penulis mencoba memberikan beberapa kesimpulan. Adapun kesimpulan yang diperoleh dari penelitian ini adalah sebagai berikut:

- Variabel Stres Kerja adanya hubungan positif yang signifikan terhadap Kinerja PMC. Hal ini terlihat dari perhitungan $\mathrm{t}$ hitung $5,722>\mathrm{t}$ tabel $(2,012)$, dengan taraf signifikan $0,000<0,05$. Nilai 5,722 lebih besar dari 2,012 menunjukan $\mathrm{t}$ hitung lebih besar dari t tabel. Dari hasil tersebut dapat disimpulkan bahwa Ha diterima. artinya bahwa ada pengaruh atau hubungan yang searah antara stres kerja terhadap kinerja secara nyata.

- Variabel Kualitas Kerja adanya hubungan positif yang signifikan terhadap Kinerja PT. PMC. Hal ini terlihat dari perhitungan $\mathrm{t}$ hitung $5,468<\mathrm{t}$ tabel $(2,012)$, dengan taraf signifikan $0,000<0,05$. Nilai 5,468 lebih besar dari 2,012. Menunjukan $\mathrm{t}$ hitung lebih besar dari t tabel, artinya Ho ditolak sehingga dapat disimpulkan bahwa ada pengaruh signifikan antara kualitas kerja terhadap kinerja.

- Stres Kerja dan Kualitas Kerja secara simultan mempengaruhi Kinerja PMC. Hal ini terlihat dari $\mathrm{F}$ hitung 85.125 dengan tingkat signifikan 0,000 sedangkan $\mathrm{f}$ tabel 3,20 dengan signifikan 0,05. Dengan demikian $\mathrm{f}$ hitung $=\mathrm{f}$ tabel yakni $85.125>3,20$ nilai 85.125 lebih besar dari 3,20 menunjukan $\mathrm{t}$ hitung lebih besar dari t tabel.

\section{Saran}

Dari hasil penelitian, analisis data, pembahasan dan kesimpulan yang telah diambil, maka dapat dikemukakan saran sebagai:

- Perusahaan perlu mengevaluasi ulang atas beban kerja yang terlalu banyak dan waktu dalam mencari alamat. Sehingga tidak menganggu dalam pengiriman document terhadap kurir. Selain itu, untuk meningkatkan kualitas pengawasan dalam menaati SOP, sebaiknya perusahaan memberikan pengawasan yang lebih untuk kurir.

- Untuk meningkatkan target yang diberikan oleh perusahaan sebaiknya kurir harus lebih giat lagi dalam melaksanakan pengiriman dokumen. Dan kurir harus memiliki tanggung jawab yang lebih atas tugas yang diberikan oleh perusahaan.

- Sebaiknya kurir lebih meningkatkan loyalitas pekerjaan agar dapat menjalankan tugas lebih maksimal dalam segi pengiriman dokumen.

- Penelitian ini terbatas hanya pada perusahaan jasa pengantaran (kurir). Diharapkan, penelitian selanjutnya dapat dilakukan pada perusahaan lain yang bergerak di industri jasa lainnya atau bisa juga meneliti perusahaan yang terdapat dalam industri manufaktur.

\section{DAFTAR PUSTAKA}

Amirullah, Firdaus. 2016. Pengaruh Stres Kerja terhadap Produktivitas Kerja Karyawan pada PT. Trijaya 
Pratama Futures MAKASAR. Universitas Islam Negeri Alauddin.

Astuti, Adhe. 2017. Hubungan Stres Kerja terhadap Produktivitas Kerja Pegawai di kantor Dinas Kebersihan di kota SAMARINDA, Universitas Mulawarman.

Handoko. T. Hani Handoko. 2000. Manajemen Personalia dan Sumber Daya Manusia. Yogyakarta: Penerbit BPFE.

Hasibuan, S. P. Malayu. 2003. Manajemen Dasar, Pengertian dan Masalah. Jakarta.

Husein, Umar. 2005. Riset Sumber Daya Manusia. Jakarta: PT. Gramedia.

Kartikasari, Dwi. 2017. Pengaruh Stres Kerja dan Motivasi terhadap Produktivitas Kerja karyawan pada PT. Epson BATAM. Universitas Politeknik Batam.

Kountur, Ronny. 2007. Metode Penelitian. Jakarta: Penerbit PPm.

Mangkunegara, A. A. Prabu. 2008. Manajemen Sumber Daya Manusia. Perusahaan. Bandung: PT. Remaja Rosdakarya.

Siregar, Roy Pria Abadi. 2008. Pengaruh Stres kerja dan Beban Kerja terhadap Kinerja Karyawan pada PT. Bank SUMUT kantor cabang SUKARAMAI MEDAN", Universitas Muhammadiyah Sumatera Utara.

Sugiyono. 2009. Metode Penelitian Kuantitatif, Kualitatif dan $R \& D$. Bandung: CV. Alfabeta.

Wicaksono, Aldy Pambudi. 2017. Pengaruh Lingkungan Kerja dan Stres Kerja terhadap Kinerja
Karyawan Depot LPG Balongan PT. Pertamina (Persero). Universitas Negeri Yogyakarta. 